\title{
Soil Profile Studies of Organic and Conventional farms growing Chilli, Capsicum annuum Kavita Choudhary', Dayanand ${ }^{2}$ and *Preeti Mishra1
}

\author{
${ }^{1}$ Plant Pathology, \\ Tissue Culture and Biotechnology Laboratory, \\ Department of Botany, \\ University of Rajasthan, \\ JAIPUR- 302004, INDIA. \\ ${ }^{2}$ Krishi Vigyan Kendra, \\ JHUNJHUNU, RAJASTHAN, INDIA \\ ${ }^{*}$ Corresponding Author \\ E-mail:drpreetipathak@gmail.com
}

Received : 25.08.2020; Revised : 08.09.2020; Accepted : 10.10.2020

\begin{abstract}
The experiments were conducted to determine effects of farming practises on soil quality of fields. Comparative analyses of soil samples from organic and conventional farms were carried out for soil organic matter nitrogen, phosphorus, potassium, salinity, and soil pH. Applications of organic manures increase the availability of organic elements in soil naturally and improve the Nutrient Use Efficiency (NUE) of crops. Standard chemical analytical methods were used to determine organic matter, EC, pH, in soil. Special attention was paid to phosphorus, nitrogen and potassium. Soil profile analysis showed that organic farming gradually enhances soil quality naturally. Results indicated increasing levels of organic carbon, total nitrogen, phosphorus, potassium, $\mathrm{CEC}, \mathrm{pH}$ of soil from farms practising organic farming.
\end{abstract}

KEY WORDS : Conventional; Farming; Organic; Soil; Sustainable agriculture.

\author{
Abbreviations \\ FYM=Farm Yard Manure \\ NUE $=$ Nutrient Use Efficiency \\ NPK = Nitrogen, Phosphorus and Potassium \\ $\mathrm{CEC}=$ Cation Exchange Capacity \\ NPOP $=$ National Program for Organic Production \\ IFOAM= International Federation of Organic Agriculture \\ Movements \\ $E C=$ Electrical Conductivity
}

\section{Introduction}

Organic farming has emerged as a progressive approach towards sustainable agriculture, producing crops without deteriorating environment. The major aim of the system is to incorporate integrated environmentally safe approaches for agricultural production. World is well aware of hazards due to usage of huge amount of synthetic fertilizers and pesticides in the conventional farming system. Green revolution increased crop yield many folds, but indiscriminate use of chemicals caused deterioration of soil quality on a large scale. The agriculture practices affect soil health and soil nutrient cycling process at large.

Agriculture alone accounts for $17.9 \%$ of the GDP (2015) of India and also incorporates approximately 50\% of the workforce ${ }^{13}$. The demand for organic products is increasing per year over the world. Studies indicate that most of the consumers purchase organic products for health, nutrient benefits and to avoid chemicals used during processing and harvesting of the food products ${ }^{30}$. Organic food quality is the main concern in attracting the consumers $^{31}$. Excessive use of chemical inputs during green revolution resulted in the rapid degradation in soil quality, biodiversity and adversely impacted farmers' health ${ }^{14}$. From a consumer perspective, the increasing quantities of pesticides and fertilizers led to contamination of food and associated health damage ${ }^{19}$. NPOP (National Program for Organic Production) has developed some standards for organic farming under guidelines of international organic production standards such as CODEX and IFOAM (International Federation of Organic Agriculture Movements). Increase in yield at conventional 
TABLE-1: Various methods used in comparative soil analysis

\begin{tabular}{|c|c|c|c|}
\hline $\begin{array}{l}\text { S. } \\
\text { No. }\end{array}$ & $\begin{array}{c}\text { Methods used in soil } \\
\text { testing kit }\end{array}$ & Nutrients & Extracting Solutions \\
\hline 1. & Olsen's method ${ }^{17}$ & Phosphorus & $0.5 \mathrm{M} \mathrm{NaHCO}_{3}, \mathrm{pH} 8.5$ \\
\hline 2. & Bray's method ${ }^{5}$ & $\begin{array}{l}\text { Phosphorus }\left(P_{1}\right) \\
\text { Phosphorus }\left(P_{2}\right) \\
\text { Potassium }\end{array}$ & $\begin{array}{l}0.025 \mathrm{~N} \mathrm{HCl}_{\text {and }} 0.03 \mathrm{~N} \mathrm{NH} 4 \mathrm{~F} 0.1 \mathrm{~N} \mathrm{HCl} \\
\text { and } 0.03 \mathrm{~N} \mathrm{NH}_{4} \mathrm{~F} 22 \% \text { sodium perchlorate, } \\
\mathrm{pH} 7.0\end{array}$ \\
\hline 3. & Troug's method ${ }^{28}$ & $\begin{array}{l}\text { Phosphorus } \\
\text { I.A.R.I. method, } \\
\text { New Delhi } \\
\end{array}$ & $\begin{array}{l}0.002 \mathrm{~N} \text { sulphuric acid containing } 3 \mathrm{gm} \text {. } \\
\left(\mathrm{NH}_{4}\right)_{2} \mathrm{SO}_{4} \text { per litre, buffered to } \mathrm{pH} 3.0 \\
1 \mathrm{~N} \text { ammonium acetate, } \mathrm{pH} 6.8\end{array}$ \\
\hline 4. & $\begin{array}{l}\text { Ammonium acetate } \\
\text { method }^{8}\end{array}$ & Potassium & $1 \mathrm{~N}$ ammonium acetate, $\mathrm{pH} 7.0$ \\
\hline 5. & Palaskar method18 & $\begin{array}{c}\text { ammoniacal } \\
\text { nitrogen, available } \\
\text { sulphur } \\
\end{array}$ & $\begin{array}{l}10 \% \text { Sodium chloride,Nessler } \\
\text { reagent, } 10 \% \text { Sodium tartrate and } \\
\text { mono-calcium phosphate } \mathrm{sol}^{\mathrm{n}}, \mathrm{BaCl}_{2}\end{array}$ \\
\hline 6. & Kjeldahl method9 & Available nitrogen & $\begin{array}{l}\text { sulfuric acid, } 60 \% \mathrm{NaOH}, 10 \% \mathrm{Na}_{2} \mathrm{~S}_{2} \mathrm{O}_{3} \text {, } \\
2 \% \text { boric acid }\end{array}$ \\
\hline 7. & $\begin{array}{l}\text { DTPA-CaCl }{ }_{2} \text {-TEA } \\
\text { method }^{11}\end{array}$ & $\begin{array}{l}\mathrm{Zn}, \mathrm{Cu}, \mathrm{Fe}, \mathrm{Mn} \\
\mathrm{B}, \mathrm{Mo}\end{array}$ & Diluted $\mathrm{HCl}$, DTPA extractant \\
\hline
\end{tabular}

farm using excess chemicals did not last long ${ }^{26}$. Organic farming leads to an improvement in soil quality, crop yield, and overall sustainability of crop production systems ${ }^{22}$ : maximises the use of farming resources; avoids the use of chemical inputs; and pesticides.

The types of pesticides and manures applied in field primarily affect nitrogen $(\mathrm{N})$ and phosphorus $(\mathrm{P})$ level in the soil - limit crop yields in many ways ${ }^{3}$. Soil indispensably play role in plant physiology ${ }^{6}$. Soil quality is important for crop growth and final yield. Organic manure compensates required elements-macro and micro- in the soil, naturally. Livestock manure returns $\mathrm{N}$ (Nitrogen), $\mathrm{P}$ (phosphorus), and $\mathrm{K}$ (potassium) (macronutrients), as well as magnesium, $\mathrm{Ca}$ (calcium), $\mathrm{S}$ (sulphur), and $\mathrm{Mn}$ (manganese) (micronutrients) to maintain the soil fertility. Nutrients available for plants improved in the experimental soil after organic manures spread, although soil microorganism were recorded variably in soils ${ }^{20}, 29$. Bacteria found in the soil are helpful to humification, decomposing, and recycling organic matters ${ }^{15}$. Microbial populations enhanace the production of plant growth regulators (gibberellin and auxin) in roots of plants that soil is rich in organic manures and increase plant growths ${ }^{1}$.

Capsicum annuum, Belong to the family
'Solanaceae', originated from South and Central American regions of the new Mexico and Guatemala region as a wild crop around $7500 \mathrm{BC}^{21}$. Cultivated species of the genus are Capsicum annuum, C. frutescens, C. chinense, C. pubescens, and C. baccatum ${ }^{24}$. The world's hottest chilli "naga jolokia" is cultivated in Tezpur, Assam. It is used as food ingredient and/or spices in many cuisines attributing their sensory, colouring, flavouring, heat, pungency and unique aroma. Capsicum annuum is an important vegetable and spice crop grown all over the country. Fruits are important source of phenolic compounds, carotenoids, ascorbic acid etc. which provide medicinal properties to it such as antibacterial ${ }^{10}$ antioxidant and anti-carcinogenic activity ${ }^{7}$.

\section{Material and Methods}

The study area were selected in Jhunjhunu district of Rajasthan $\left(28.1317^{\circ} \mathrm{N}, 75.4022^{\circ} \mathrm{E}\right)$. The farms converted from conventional to organic farming take time to modify soil content. Three types of agriculture farms for organic farming were selected. Soil samples from organic farms and conventional farms growing chili were taken. The soil samples named ORG I (collected from farms practicing organic farming since 2-3 years), ORG II (collected from farms practicing organic farming for 5-6 years), ORG III (collected from farms practicing organic 
TABLE-2: Results of soil analysis of organic and conventional farms growing chilli.

\begin{tabular}{l|l|l|l|l|l}
\hline S.No. & Name of Compound(unit) & ORG I & ORG II & ORG III & CON \\
\hline 1 & $\mathrm{pH}$ & 8.30 & 8.32 & 8.83 & $\mathbf{8 . 2 5}$ \\
\hline 2 & Electritical conductivity & 0.29 & 0.25 & 0.22 & $\mathbf{0 . 4 1}$ \\
\hline 3 & Organic carbon (\%) & 0.31 & 0.34 & $\mathbf{0 . 3 9}$ & 0.37 \\
\hline 4 & Phosphate(per kg) & 25 & 28 & $\mathbf{3 6}$ & 22 \\
\hline 5 & Potash(per kg) & 320 & 335 & $\mathbf{3 4 2}$ & 330 \\
\hline 6 & Zn(ppm) & 0.60 & 0.68 & $\mathbf{0 . 7 2}$ & 0.52 \\
\hline 7 & Fe(ppm) & 4.26 & 4.92 & $\mathbf{5 . 2 2}$ & 4.20 \\
\hline 8 & $\mathrm{Cu}(\mathrm{ppm})$ & 0.22 & 0.28 & $\mathbf{0 . 3 2}$ & 0.20 \\
\hline 9 & $\mathrm{Mn}(\mathrm{ppm})$ & 2.24 & 2.22 & $\mathbf{3 . 2 0}$ & 2.20 \\
\hline 10 & $\mathrm{~S}(\mathrm{ppm})$ & 22.4 & 28.2 & $\mathbf{3 2 . 4}$ & 16.8 \\
\hline 11 & Available N(kg/ha) & $170-190$ & $195-205$ & $\mathbf{2 1 5 - 2 2 5}$ & $150-165$ \\
\hline
\end{tabular}

farming for 7-8 years) and CON (collected from conventional farms) were taken for the analysis.

\section{Soil Analyses}

We collected soil samples from $0-15 \mathrm{~cm}$ soil depth near the rhizosphere. Collected samples of soil were first air-dried, removed debris or grounded mechanically. In soil testing, physical, physio-chemical and chemical test determining texture, $\mathrm{pH}$ (soil reaction), electrical conductivity, organic carbon, mineralizable nitrogen, available phosphorous and potassium to know soil fertility and productivity. We analyzed soil samples according to the methods developed by the National Institute of Agricultural Science and Technology ${ }^{16}$. Application of fertilizers for conventional farming was $100 \mathrm{~kg}$ ha-1 of urea and $250 \mathrm{~kg}$ ha- 1 of NPK, while for organic practitioners give input like animal waste, compost and green manure as required. Analyses for soil organic-Carbon, Nitrogen, available-phosphorus, available-potassium, $\mathrm{CEC}$ ), and pH parameters were done.

\section{Results and Discussion}

Data suggested that fields practicing organic farming soil are significantly better in $\mathrm{pH}, \mathrm{CEC}$ (cation exchange capacity) and base saturation levels contrasting to conventional farms. Soil pH determine microorganisms' community structure and diversity ${ }^{27}$, which invariably controls the decomposition and nitriûcation. Long-term FYM/manure addition increased CEC due to the colloidal nature of organic matter and increase soil fertility or yield. Continuous use of inorganic chemicals reduced the organic carbon content of soil (Table-2). Available nitrogen in soil significantly increased with application of green manure. Available Nitrogen is very high in organic 3year field i.e. (215 to $225 \mathrm{~kg}$ per ha) while low in conventional field (150 to $165 \mathrm{~kg}$ per ha) (Table-2). Chemical fertilizers decreased the availability of $\mathrm{Ca}$ and $\mathrm{Mg}$, while the application of FYM increased the levels of exchangeable $\mathrm{Ca}$ and $\mathrm{Mg}$. $\mathrm{Fe}, \mathrm{Mn}, \mathrm{Zn}$ and Cu contents.

Our results show $\mathrm{P}, \mathrm{K}, \mathrm{Zn}, \mathrm{Fe}, \mathrm{Cu}, \mathrm{Mn}, \mathrm{S}$ gradually increase in organic fields with time (Table 2). The levels of nutrients at conventional farm, especially where urea and NPK fertilizers were readily used, they are water soluble and leach out easily. Earlier workers reported leaching of fertilizers from soil of organic farms was Much lower (30-50\%) than conventional farming systems ${ }^{2,25}$. In our study we found that $\mathrm{pH}$ of organic field was slightly higher (8.83) compared to conventional field (8.25). Total organic carbon assistances to recover soil texture, capacity to exchange cation and water holding, thus exerts constructive impact on soil fertility and overall health ${ }^{4,12}$.

The results from soil analysis were very encouraging and indicating that soil of organic field has good parameters like $\mathrm{pH}, \mathrm{EC}$ and all micro and 

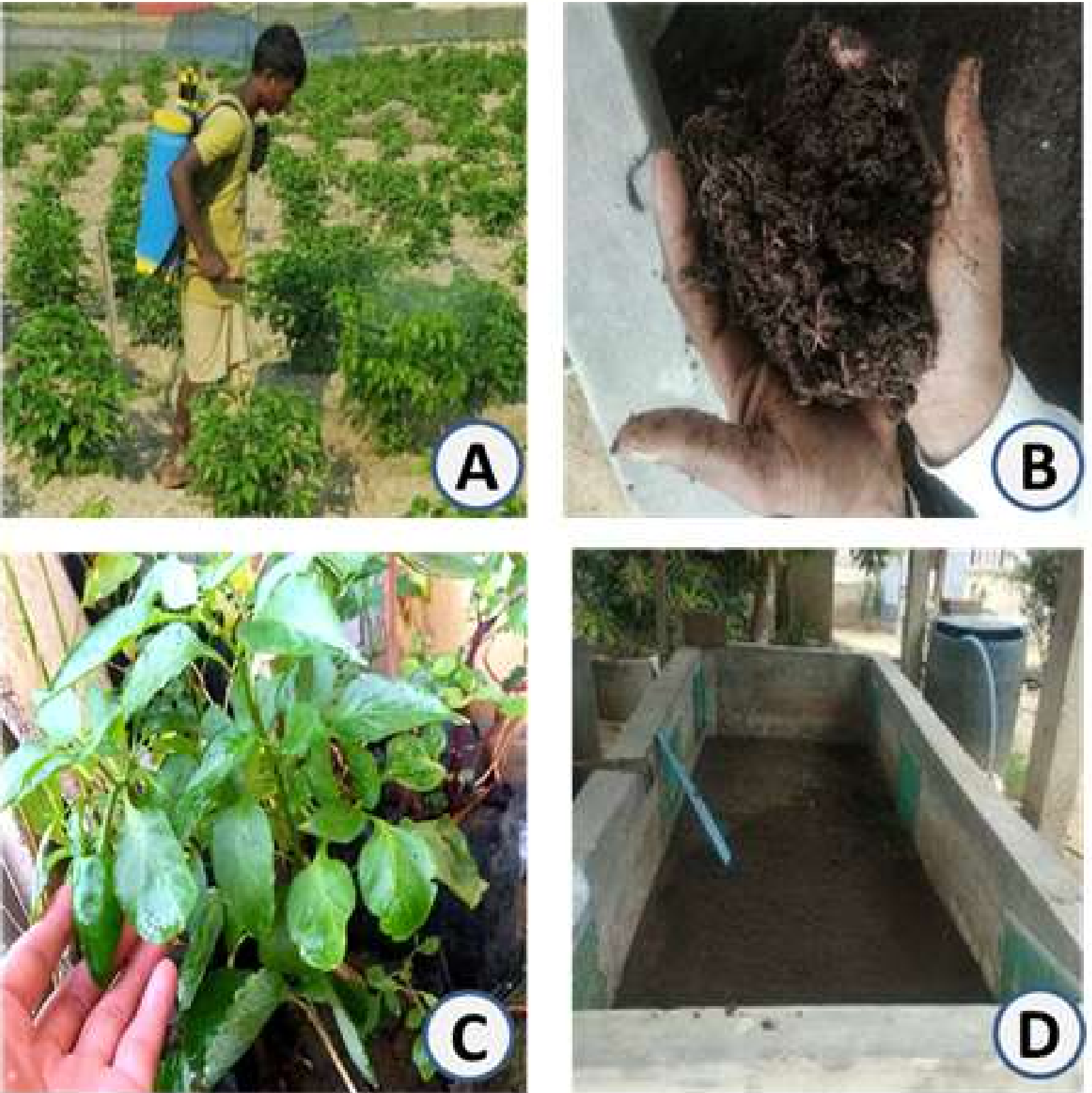

Fig. 1 : Various practices of farming for chilli crop; (A) Farmer spraying pesticides on chilli crop; (B) Vermi compost prepared by farmer to increase soil fertility; (C) Organic growing chilli; (D) Vermi compost bed.

macronutrients. The level of NPK has shown significantly higher results in an organic soil sample. Availability of nutrients changes in soil carbon, nitrogen recycling augments plant defense mechanism and soil fertility increase due to support of microflora growth.

\section{References}

1. Albiach R, Canet R, Pomares F, Ingelmo F. Microbial biomass content andenzymatic activities after the application of organic amendments to a horticultural soil. Bioresour. Technol. 2002; 75: 43-48.

2. Benoit MJ, Garnier J, Anglade, Billen G. Nitrate leaching from organic and conventional arable crop farms in the Seine Basin (France). Nutr Cycl Agroecosyst. 2014; 100: 285-299. 
3. Bhatt $\mathrm{M}$, Labanya $\mathrm{R}$, Joshi $\mathrm{H}$. Influence of Long-term Chemical fertilizers and Organic Manures on Soil Fertility -A Review. Universal Journal of Agricultural Research. 2019; 7: 177-188. DOI 10.13189/ujar.2019.070502.

4. Blécourt M, Gröngröft A, Baumann S, Eschenbach A. Losses in soil organic carbon stocks and soil fertility due to deforestation for low-input agriculture in semi-arid southern Africa. Journal of Arid Environments. 2019; 165: 88-96. DOI 10.1016/j.jaridenv.2019.02.006.

5. Bray RH, Kurtz, LT. Determination of total, organic and available forms of phosphorus in soils. Soil Science. 1945; 59: 39-45.

6. Chludil H, Corbino GB, Leicach SR. Soil quality effects on Chenopodium album flavonoid content and antioxidant potential. J. Agric. Food Chem. 2008; 56: 5050-5056.

7. Haegele AD, Gillette C, O'Neill C, Wolfe P, Heimendinger J, Sedlacek S, Thompson, HJ. Plasma xanthophyll carotenoids correlate inversely with indices of oxidative DNA damage and lipid peroxidation AMC cancer. Cancer Epid. Biomarkers \& Prev. 2002; 9: 421-425.

8. Hanway JJ, Heidal H.. Soil analysis, as used in lowa State. College of Soil Testing Laboratory, lowa. Agriculture.1952; $57: 1-31$.

9. Kjeldahl J. New Method for the Determination of Nitrogen. Chem. News. 1883; 48 (1240):101-102.

10. Koffi-Nevry R, Kouassi CK, Zinzerdof YN, Marina K, Guillaume YL. Antibacterial Activity of Two Bell Pepper Extracts: Capsicum annuum L. and Capsicum frutescens, International Journal of Food Properties. 2012; 15(5): 961-971.

11. Lindsay WL, Norvell WA. Development of a DTPA soil test for zinc, iron, manganese, and copper. Soil Science Society of America Journal. 1978; 42: 421-428.

12. Liu M, Han G, Zhang Q, Song Z. Variations and indications of d13CSOC and d15NSON in soil profiles in Karst Critical Zone Observatory (CZO) Southwest China. Sustainability. $2019 ; 11: 2144$.

13. Mahapatra BS, Goel R, Shukla A, Diwedi GK. Organic agriculture technology and sustainability. 4th International Agronomy Congress. 2016; 4: 66-67.

14. Mittal S, Kaur G, Vishwakarma GS. Effects of environmental pesticides on the health of rural communities in the Malwa Region of Punjab, India: A review. Human and Ecological Risk Assessment: An International Journal. 2014 20(2): 366-387.

15. Nguyen NL, Kim YJ, Hoang VA, Subramaniyam S, Kang JP, Kang CH, Yang DC. Bacterial Diversity and Community Structure in Korean Ginseng Field Soil Are Shifted by Cultivation Time. PLoS ONE. 2016; 11 : e0155055.

16. NIAST. Method of Soil and Plant Analysis; National Institute of Agricultural Science and Technology: Suwon, Korea. 2000.

17. Olsen SR, Cole CV, Watanabe FS, Dean LA. Estimation of available phosphorus in soils by extraction with NaHCO3, USDA Cir.939. U.S. Washington.1954.

18. Palaskar MS, and Ghosh AB. Evaluation of some soil tests: Methods for available sulfur using cabbage as a test crop. Journal of Nuclear Agriculture and Biology. 1981;10:88-91.

19. Pandey J, Singh A. Opportunities and constraints in organic farming: An Indian perspective. Journal of Scientific Research. 2012; 56: 47-72.

20. Parham J, Deng S, Raun W, Johnson G. Long-term cattle manure application in soil. Biol Fertil Soils. 2002; 35:328-337.

21. Perry L. Starch fossils and the domestication and dispersal of chilli pepper (Capsicum spp. L.) in the Americas. Science. 2007; 315: 986-988.

22. Rupela OP, Humayun P, Venkateswarlu B, Yadav AK. Comparing conventional and organic farming crop production systems: Inputs, minimal treatments and data needs. Organic Farming Newsletter. 2006; 2(2): 3-17.

23. Sacco DM, Barbara M, Stefano, Carlo G. Sixyear transition from conventional to organic farming: effects on crop production and soil quality. Europ J Agronomy. 2015; 69: 10-20. 
24. Saleh BK, Omer A, Teweldemedhin B. Medicinal uses and health benefits of chilli pepper (Capsicum spp.): a review. J. Food Process Technol. 2018; 6(4): 325328.

25. Stopes CE, Lord L, Philipps, Woodward L. Nitrate leaching from organic farms and conventional farms following best practice. Soil Use Manage. 2002; 18: 256-263.

26. Sutanto R. Penerapan Pertanian Organik. Kanisius. Yogyakarta. 2002.

27. Tripathi BM, Stegen JC, Kim M, Dong K, Adams JM, Lee YK. Soil pH mediates the balance between stochastic and deterministic assembly of bacteria. ISME Journal. 2018; 12(4):1072-1083 DOI 10.1038/s41396-018-0082-4.

28. Troug E. Fifty years of soil testing, Transactions of 7 th International Congress of soil Science, Madison Wisconsin, USA, Part III and IV. 1960; 36-45.

29. Wang S, Zhang W, Sanchez F. Relating net primary productivity to soil organic matter decomposition rates in pure and mixed Chinese fir plantations. Plant Soil. 2010; 334:501-510.

30. Winter CK, Davis SH. Organig foods. J Food Sci. 2006; 71(9): 117-124.

31. Zander K, Hamm U. Consumer preferences for additional ethical attributes of organic food. Food Quality and Preference. 2010; 21(5): 495-503. 